Prepared in cooperation with the Bureau of Reclamation

Evaluation of LiDAR-Acquired Bathymetric and Topographic Data Accuracy in Various Hydrogeomorphic Settings in the Lower Boise River, Southwestern Idaho, 2007

Scientific Investigations Report 2009-5260 



\section{Evaluation of LiDAR-Acquired Bathymetric and Topographic Data Accuracy in Various Hydrogeomorphic Settings in the Lower Boise River, Southwestern Idaho, 2007}

By Kenneth D. Skinner

Prepared in cooperation with the

Bureau of Reclamation

Scientific Investigations Report 2009-5260 


\section{U.S. Department of the Interior \\ KEN SALAZAR, Secretary}

\section{U.S. Geological Survey \\ Marcia K. McNutt, Director}

U.S. Geological Survey, Reston, Virginia: 2009

For more information on the USGS - the Federal source for science about the Earth, its natural and living resources, natural hazards, and the environment, visit http://www.usgs.gov or call 1-888-ASK-USGS

For an overview of USGS information products, including maps, imagery, and publications, visit http://www.usgs.gov/pubprod

To order this and other USGS information products, visit http://store.usgs.gov

Any use of trade, product, or firm names is for descriptive purposes only and does not imply endorsement by the U.S. Government.

Although this report is in the public domain, permission must be secured from the individual copyright owners to reproduce any copyrighted materials contained within this report.

Suggested citation:

Skinner, K.D., 2009, Evaluation of LiDAR-acquired bathymetric and topographic data accuracy in various hydrogeomorphic settings in the lower Boise River, southwestern Idaho, 2007: U.S. Geological Survey Scientific Investigations Report 2009-5260, 12 p. 


\section{Contents}

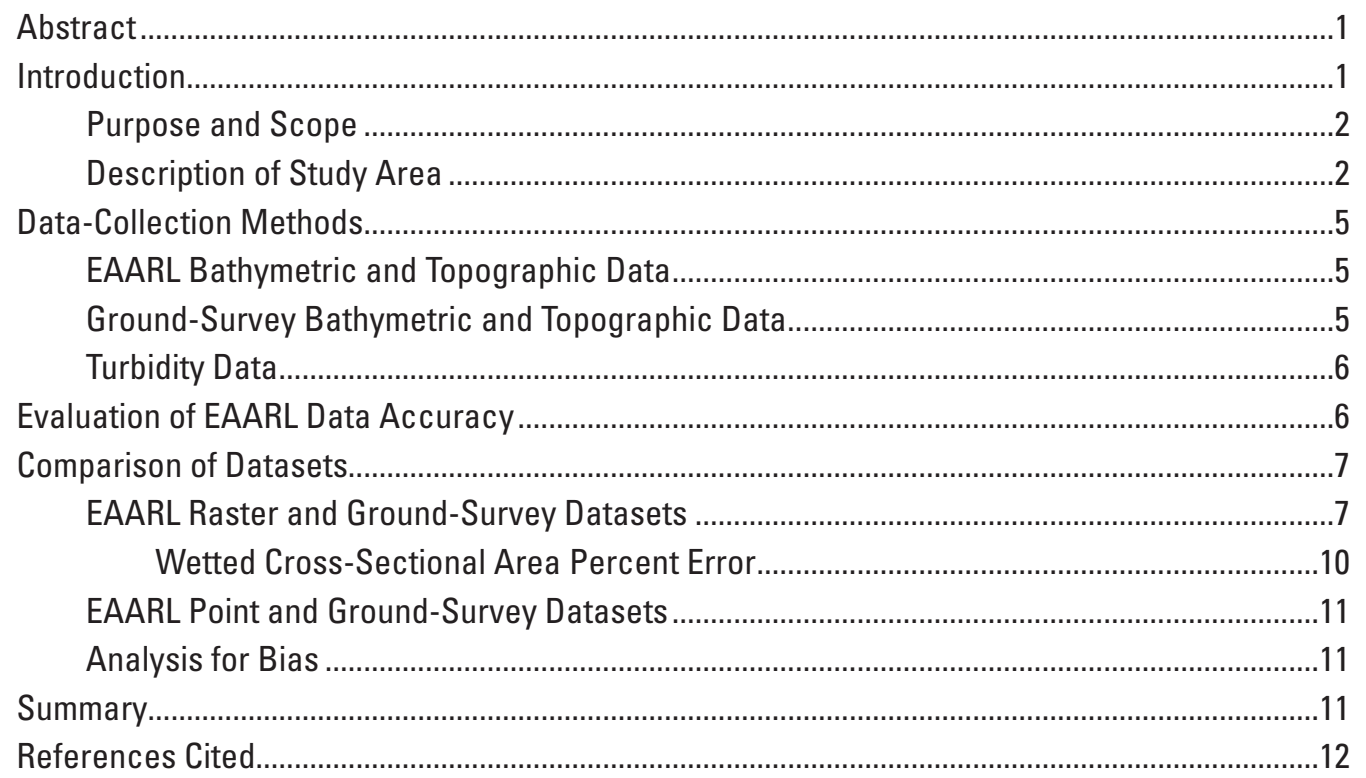

\section{Figures}

Figure 1. Maps showing EAARL and ground-survey data collection areas and data collection locations within the areas along the lower Boise River, southwestern Idaho

Figure 2. Graphs showing EAARL raster and ground-survey elevations at two transects,

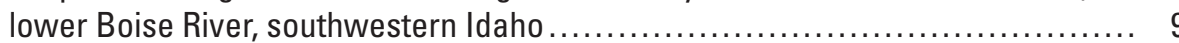

Figure 3. Graph showing EAARL raster and ground-survey data at transect 4 of ground-survey area 3, lower Boise River, southwestern Idaho ................ 10

\section{Tables}

Table 1. Comparison of EAARL bare earth/bathymetry raster datasets to ground-survey

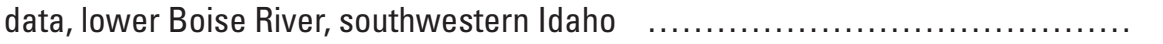

Table 2. Comparison of EAARL bare-earth/bathymetry point datasets to ground-survey data within a 1-meter radius, lower Boise River, southwestern Idaho 


\section{Conversion Factors, Datums, and Acronyms and Abbreviations}

SI to Inch/Pound

\begin{tabular}{lcl}
\hline \multicolumn{1}{c}{ Multiply } & By & To obtain \\
\hline & Length & \\
\hline centimeter $(\mathrm{cm})$ & 0.3937 & inch (in.) \\
kilometer $(\mathrm{km})$ & 0.6214 & mile (mi) \\
millimeter (mm) & 0.03937 & inch (in.) \\
meter $(\mathrm{m})$ & 3.281 & foot (ft) \\
meter $(\mathrm{m})$ & 1.094 & yard (yd) \\
\hline & Area & \\
\hline square kilometer $\left(\mathrm{km}^{2}\right)$ & 247.1 & acre \\
square kilometer $\left(\mathrm{km}^{2}\right)$ & 0.3861 & square mile (mi²) \\
\hline
\end{tabular}

Temperature in degrees Celsius $\left({ }^{\circ} \mathrm{C}\right)$ may be converted to degrees Fahrenheit ( $\left.{ }^{\circ} \mathrm{F}\right)$ as follows:

${ }^{\circ} \mathrm{F}=\left(1.8 \mathrm{x}^{\circ} \mathrm{C}\right)+32$.

Temperature in degrees Fahrenheit $\left({ }^{\circ} \mathrm{F}\right)$ may be converted to degrees Celsius $\left({ }^{\circ} \mathrm{C}\right)$ as follows:

${ }^{\circ} \mathrm{C}=\left({ }^{\circ} \mathrm{F}-32\right) / 1.8$.

Datums

Vertical coordinate information is referenced to the North American Vertical Datum of 1988 (NAVD 88).

Horizontal coordinate information is referenced to the North American Datum of 1983 (NAD 83).

Acronyms and Abbreviations

$\begin{array}{ll}\text { ALPS } & \text { Airborne LiDAR Processing System } \\ \text { DEM } & \text { digital elevation model } \\ \text { EAARL } & \text { Experimental Advanced Airborne Research LiDAR } \\ \text { GPS } & \text { Global Positioning System } \\ \text { IDWR } & \text { Idaho Department of Water Resources } \\ \text { LIDAR } & \text { Light Detection and Ranging } \\ \text { ME } & \text { mean signed error } \\ \text { n.d. } & \text { not defined } \\ \text { NTU } & \text { Nephelometric Turbidity Unit } \\ \text { OPUS-S } & \text { Static Online Positioning User Service } \\ \text { RKM } & \text { river kilometer } \\ \text { RMSE } & \text { root mean square error } \\ \text { RTK-GPS } & \text { real-time kinetic global positioning system } \\ \text { USGS } & \text { U.S. Geological Survey }\end{array}$




\title{
Evaluation of LiDAR-Acquired Bathymetric and Topographic Data Accuracy in Various Hydrogeomorphic Settings in the Lower Boise River, Southwestern Idaho, 2007
}

\author{
By Kenneth D. Skinner
}

\section{Abstract}

Elevation data in riverine environments can be used in various applications for which different levels of accuracy are required. The Experimental Advanced Airborne Research LiDAR (Light Detection and Ranging) — or EAARL—system was used to obtain topographic and bathymetric data along the lower Boise River, southwestern Idaho, for use in hydraulic and habitat modeling. The EAARL data were post-processed into bare earth and bathymetric raster and point datasets.

Concurrently with the EAARL data collection, real-time kinetic global positioning system and total station groundsurvey data were collected in three areas within the lower Boise River basin to assess the accuracy of the EAARL elevation data in different hydrogeomorphic settings. The accuracies of the EAARL-derived elevation data, determined in open, flat terrain, to provide an optimal vertical comparison surface, had root mean square errors ranging from 0.082 to $0.138 \mathrm{~m}$. Accuracies for bank, floodplain, and in-stream bathymetric data had root mean square errors ranging from 0.090 to $0.583 \mathrm{~m}$. The greater root mean square errors for the latter data are the result of high levels of turbidity in the downstream ground-survey area, dense tree canopy, and horizontal location discrepancies between the EAARL and ground-survey data in steeply sloping areas such as riverbanks.

The EAARL point to ground-survey comparisons produced results similar to those for the EAARL raster to ground-survey comparisons, indicating that the interpolation of the EAARL points to rasters did not introduce significant additional error. The mean percent error for the wetted crosssectional areas of the two upstream ground-survey areas was 1 percent. The mean percent error increases to -18 percent if the downstream ground-survey area is included, reflecting the influence of turbidity in that area.

\section{Introduction}

The lower Boise River and its associated floodplain is a central feature of the Treasure Valley in southwestern Idaho and as a result is affected by impacts from population growth and development. Primary issues related to the river include flooding, water quality, and water supply. To address these and other issues effectively, responsible Federal, State, and local agencies must have high-quality environmental data with which to make sound water-management decisions. The Bureau of Reclamation (Reclamation) coordinated efforts to acquire high-resolution bathymetric and topographic data along the Lower Boise River and its floodplain from Lucky Peak Dam to the confluence with the Snake River. The data are essential to Reclamation's need for hydraulic and physical habitat modeling while also creating an elevation dataset useful for other agencies. These data were collected from a National Aeronautics and Space Administration aircraft using the Experimental Advanced Airborne Research LiDAR System (EAARL). Light detection and ranging (LiDAR) remote-sensing technology uses laser pulses to measure the distance from the laser to topographic and bathymetric surfaces. The EAARL system uses a green laser to penetrate water bodies, and map riverbeds as well as banks and floodplains.

LiDAR data are collected as high-density point clouds that commonly are interpolated into a continuous elevation grid or digital elevation model (DEM). The DEM provides evenly spaced elevation data over an entire study area. This is an improvement over traditional survey methods that provide discontinuous data only at the locations where measurements or observations are made. Moreover, land access to desired data-collection areas can be limited by private property or other restrictions, and the size of traditional survey datasets is limited by time and cost restrictions. With the EAARL system, an entire survey area can be overflown and imaged in as little as 1 day. 
Because of the several proposed and potential applications of the EAARL data for the lower Boise River, the accuracy requirements of the data differ. For example, evaluating the distribution of pools and riffles in an analysis of fish habitat requires a qualitative level of data accuracy, whereas hydraulic modeling associated with flood mapping requires a much higher degree of data accuracy (Bales and others, 2007; Barlow and others, 2008). Certain environmental settings affect the accuracy of LiDAR-acquired topographic and bathymetric data, such as the density of the tree canopy, ground slope, water depth, and turbidity. As a result, the LiDAR-acquired data must be evaluated under varying hydrogeomorphic settings to determine the accuracy of the data, thereby ensuring that the data meet the basic standards required for their intended applications.

Ground-truth survey data provides the necessary means to determine the accuracy of LiDAR-acquired data. The ground-truth data, GPS and total station survey data, must be collected at a higher degree of accuracy than that expected of the LiDAR dataset; ground-truth data also must represent the same hydrogeomorphic settings that exist within the LiDAR data collection areas (American Society of Photogrammetry and Remote Sensing, 2004). Ground-truthing is necessary when a high-degree of data accuracy is required, and the ground-truth data must be collected in enough quantities at enough locations to evaluate the LiDAR-acquired data in all hydrogeomorphic settings present.

The U.S. Geological Survey (USGS) in cooperation with Reclamation collected ground-truth data in three separate areas coincident with the EAARL data and made statistical comparisons between the two datasets within similar hydrogeomorphic categories to evaluate the accuracy of the EAARL data collected along the lower Boise River and its floodplain.

\section{Purpose and Scope}

This report provides an evaluation of the elevation accuracy of the EAARL-acquired data in different hydrogeomorphic settings in the lower Boise River. This evaluation compares the EAARL-acquired data with groundsurvey data collected using a survey grade, real-time kinetic global positioning system (RTK-GPS) and a total station. The ground-survey data were collected in three areas within the lower Boise River; each "area" comprised five transects across the Boise River. Ground- survey data were collected along the stream channel, banks, and floodplains; and a grid of points were surveyed in a flat-open surface in each area. The three ground-survey areas consist of varying tree canopy densities, stream turbidity, and substrates. They were selected to assess the accuracy of EAARL-derived elevations in various hydrogeomorphic settings.

\section{Description of Study Area}

The lower Boise River is the 103-km reach from Lucky Peak Dam to the confluence with the Snake River (fig. 1). This reach of the Boise River is in the 3,440-km² lower Boise River basin and flows predominantly northwest. The basin is semiarid; most of the surface water originates in the 6,960$\mathrm{km}^{2}$ upper Boise River basin, upstream of Lucky Peak Dam.

The EAARL system collected data in a 2-5 km-wide swath along the entire 103-km reach of the lower Boise River (ig. 1). Three ground-survey areas within the larger area covered by the EAARL data were selected to represent different hydrogeomorphic settings. Ground-survey area 1 is the farthest upstream in the basin, at approximately river kilometer (RKM) 95. Ground-survey area 2 is at RKM 68 in the north channel of the Boise River in Eagle. Ground-survey areas 1 and 2 each extend for about a kilometer along the river. Due to access constraints in ground-survey area 3 , this area spans river kilometers 3 to 8 , southwest of Parma.

In ground-survey area 1 , tree cover is dense along the southern bank of the Boise River, but few trees or shrubs are present on the northern side of the river. The river has cobble substrate and sandy banks in this area.

Tree cover is dense on both banks of the Boise River in the two upstream transects of ground-survey area 2, but is minimal in the three downstream transects of this area. Twostory office buildings line the northern side of the Boise River along transects $1-4$. Stream substrate in ground-survey area 2 is predominantly cobbles and gravels.

Ground-survey area 3 has very little vegetation near the surveyed transects. Substrate in this area varies from silt and sand to gravel and cobble.

Data were collected within each of the three groundsurvey areas along five transects surveyed at wadable locations. The cross-sections were located to represent various channel and bank or floodplain settings, including areas under tree canopy as well as in open areas and steep banks. In addition, at each of the three areas, a grid of 100 survey points at a 2-m spacing was surveyed on the floodplain. These surveyed grids were located on flat, open terrain to provide an optimal vertical comparison surface for the EAARL and ground-survey data. Collection of the EAARL and groundsurvey data occurred simultaneously during March 16-21, 2007, to ensure the two datasets were representative of the same environmental conditions. Data were collected during leaf-off conditions to minimize the effects of the vegetation on the EAARL system. 

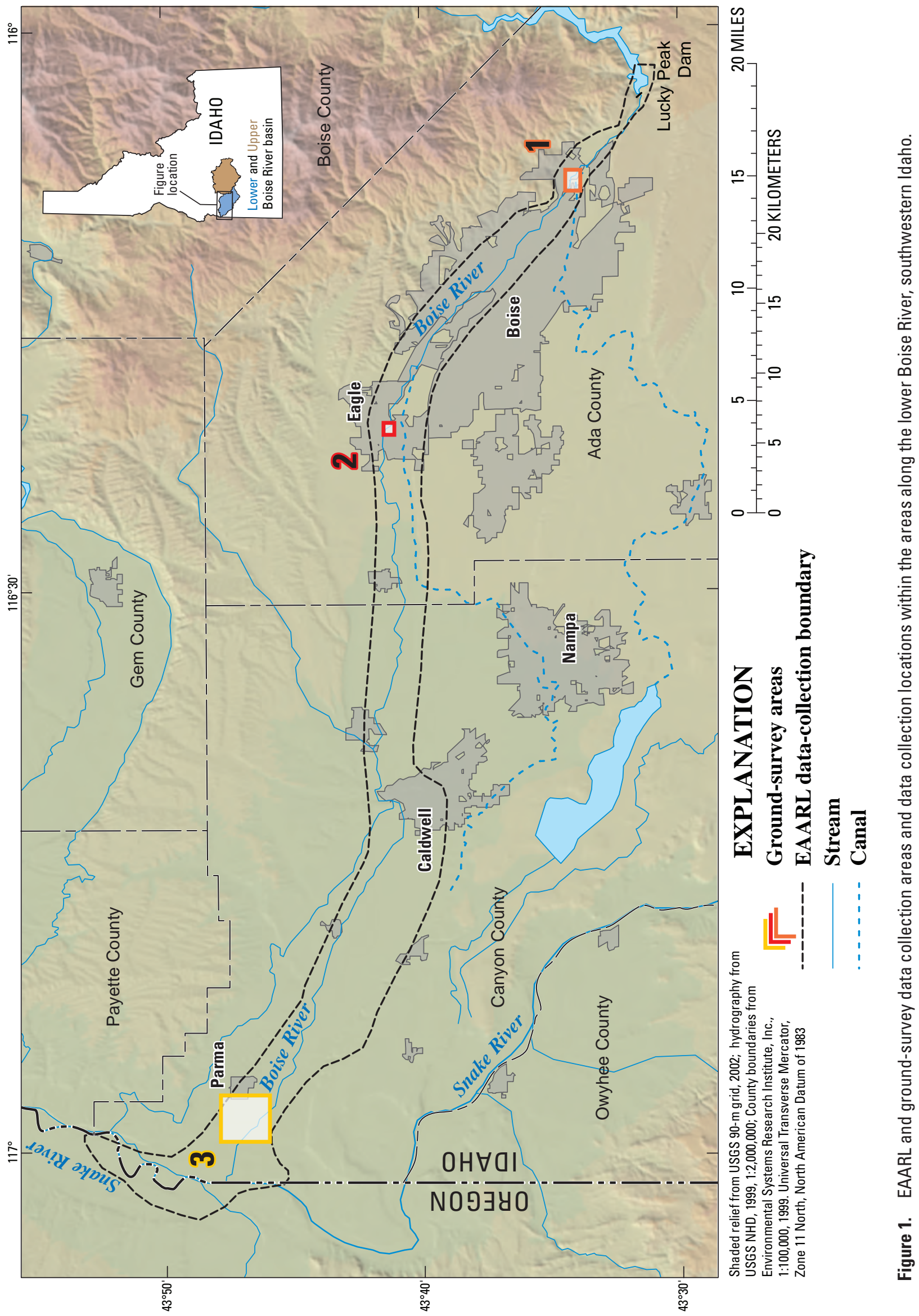

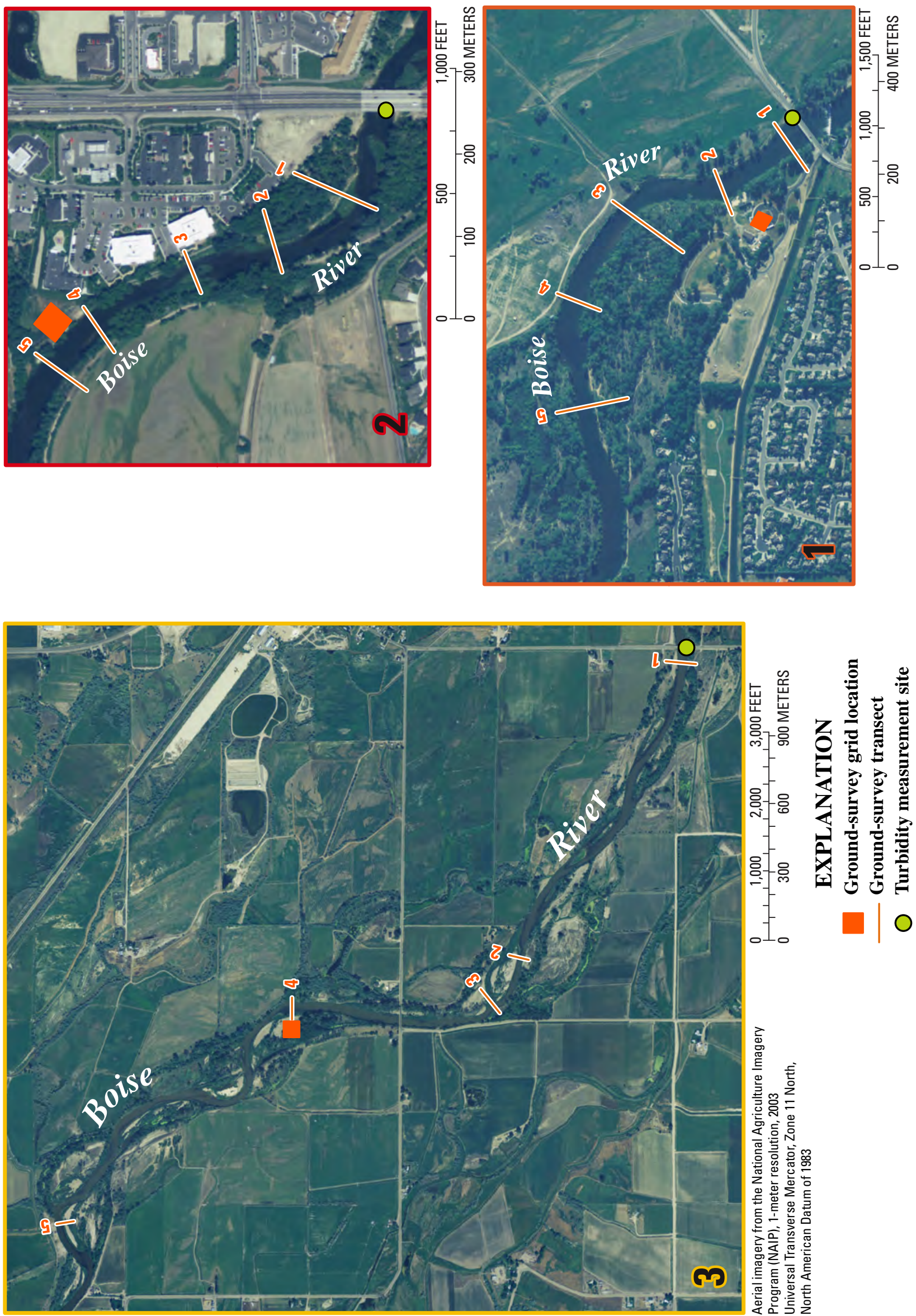

헝 


\section{Data-Collection Methods}

To evaluate the accuracy of the EAARL data, bathymetric and topographic elevation data were collected using traditional ground-surveying methods with known standards of accuracy. The ground-survey data were collected at three locations along the lower Boise River (fig. 1): one in the upstream reach, one in the mid-reach, and one in the downstream reach. The characteristics of the three ground-survey data-collection areas provided a basis for assessing the accuracy of the EAARL data under various environmental settings, such as varying water depths, substrates, and turbidity levels.

\section{EAARL Bathymetric and Topographic Data}

The EAARL system uses a green-wavelength (532 $\mathrm{nm}$ ) LiDAR designed to map bathymetry, topography, and vegetation simultaneously. The system under nominal conditions measures laser pulses at $2 \times 2-\mathrm{m}$ spacing in the center of a 240-m swath and extending to $2 \times 4-\mathrm{m}$ spacing on the edges of the swath. The EAARL laser has a spot diameter of $20 \mathrm{~cm}$ when flown at the nominal surveying elevation of $300 \mathrm{~m}$ above ground level. In addition to the LiDAR sensor, the EAARL system includes two down-looking cameras, an RGB (red, green, blue) digital camera and a multispectral infrared camera, two dual-frequency GPS (Global Positioning System) receivers, and an integrated digital inertial measurement unit. A complete description of the EAARL system and related publications is available at U.S. Geological Survey (2007a) and Nayegandhi (2009).

The Idaho Department of Water Resources (IDWR) conducted the post-flight EAARL data processing using the Airborne LiDAR Processing System (ALPS). ALPS was developed in collaboration between the National Aeronautics and Space Administration and the USGS (U.S. Geological Survey, 2007b). The ALPS-generated point elevation locations were provided to the USGS for analysis as three separate datasets: bathymetric, bare earth, and first surface. The bathymetric data, which represents the stream bottom, was clipped to the submerged areas; the bare earth points were removed from these areas and exist only in the terrestrial areas. The bare earth data represent the ground surface excluding vegetation or manmade structures. The first surface data are represented by the first return of the LiDAR laser, typically from the top of vegetation, and were not evaluated in this report. The EAARL raster elevation datasets provided by IDWR consist of two raster datasets: a first-surface dataset and a combined bare-earth/bathymetry dataset, each with a 2-m resolution and created from the corresponding ALPSgenerated point elevation locations. All datasets have a spatial reference of Universal Transverse Mercator Zone 11 North with the North American Horizontal Datum of 1983 and the North American Vertical Datum of 1988.

\section{Ground-Survey Bathymetric and Topographic Data}

Ground-survey data were collected by use of a survey grade real-time kinetic global positioning system (RTK GPS) and a total station in areas of poor RTK GPS performance, primarily areas with high tree densities. The RTK GPS system provides an accuracy of $1 \mathrm{~cm}$ horizontally and $2 \mathrm{~cm}$ vertically (Trimble, 2003); the total station has an accuracy of $2 \mathrm{~mm}$.

Bathymetric and topographic data were collected along five transects across the Boise River at each of the three ground-survey areas. Data also were collected at each of the three survey areas within a grid of 100 points spaced at about 2-m intervals in a flat, open area on the floodplain next to the river. Within each of the areas, transects across the Boise River were numbered, starting at the upstream reaches and increasing downstream. The transects comprised survey points across the river that were spaced at about 2-m intervals, with additional survey points collected in certain areas to accurately define changes in slope of the streambed profile, the water surface at each bank, and the thalweg of the stream. Water depth was calculated for each transect by simply subtracting the thalweg elevation from the water-surface elevation.

Each ground-survey point was coded according to the hydrogeomorphic setting in which it resided. The three hydrogeomorphic settings were: (1) stream channel, in which survey points were measured on the submerged stream channel; (2) streambank, which extended from the water's edge up to the level of the floodplain; and (3) the floodplain itself. Each transect had different numbers of ground-survey points in each hydrogeomorphic setting depending on the shape and size of the setting. The separation of the streambank and floodplain settings enabled comparison of conditions along the high relief of the bank to those on the relatively flat surface of the floodplain, each of which affects the performance of the EAARL system differently. A binary code was added to field data collected in each hydrogeomorphic setting to denote the presence of any trees in the immediate vicinity of the data- collection point.

Data within each grid of ground-survey points were collected at the largest available flat open surface. Thus, the three grids were surveyed on three different surface types: the upper ground-survey area near Barber Park was an asphalt parking lot; the middle area near Eagle was a flat field of short grasses; and the downstream area near Parma was a large flat cobble bar.

The RTK GPS data were collected using the 2003 geoid model (Roman and others, 2004) and post-processed along with the total station data in Trimble Geomatics Office software (Trimble Navigation Limited, 2005). The groundsurvey data were referenced to the National Geodetic Survey's Continuously Operating Reference Station (CORS) network 
(Snay and Soler, 2008) by establishing accurate base-station locations using the Static Online Positioning User Service (OPUS-S) (Weston and others, 2007). This method allowed all three ground-survey areas to be referenced to the same control network. Comparisons to existing benchmarks were made to test the accuracy of the survey and the local performance of the 2003 geoid model. The ground-survey data have the same spatial reference as the EAARL data: Universal Transverse Mercator Zone 11 North with the North American Horizontal Datum of 1983 and the North American Vertical Datum of 1988.

\section{Turbidity Data}

Three turbidity measurement sites from the waterelevation database compiled by the Bureau of Reclamation (Donna Pitzer, written commun., 2007) lie within the EAARL and ground-survey data collection areas (fig. 1). The turbidity values are 2.7, 4.2, and 19.3 Nephelometric Turbidity Units (NTU), respectively, for ground-survey areas 1, 2, and 3. The turbidity measurement sites are at the upstream end of each corresponding ground-survey area. The turbidity data was collected concurrent with the EAARL and ground-survey data. The turbidity values increase in a downstream direction at each ground-survey area, with the largest increase of turbidity occurring at ground-survey area 3.

\section{Evaluation of EAARL Data Accuracy}

The ground-survey data were compared to both the EAARL bare-earth/bathymetry raster and point datasets. The EAARL raster dataset comparisons were made in a GIS by extracting the EAARL raster elevation value to the groundsurvey point that coincided at that location. The EAARL point datasets were compared with the ground-survey data in a GIS by locating the nearest EAARL point within 1-m distance to each of the ground-survey points. The 1-m distance limitation minimizes the ground-slope change between the two comparison points. Not every ground-survey point had an EAARL point within the 1-m radius. The EAARL point's value was then related back to the nearest ground-survey point. The combined ground-survey point and raster elevation datasets were then exported to another software package for statistical analysis.

Although the EAARL point datasets provide a direct point-to-point comparison with the ground- survey data, the EAARL raster datasets do not provide such a comparison because an actual EAARL data point does not exist for every raster cell. Therefore, the EAARL raster to ground-survey comparison takes into account the effects of the interpolator used to infer elevations at all cell locations.
To evaluate the differences between the EAARL elevation datasets and the ground-survey data, the root mean square error (RMSE) and the mean signed error (ME) statistics were calculated for each hydrogeomorphic setting to evaluate performance under those conditions. The RMSE and ME are defined as:

$$
R M S E=\sqrt{\frac{\sum_{i=1}^{n}\left(Z_{i L i D A R}-Z_{\text {iground }}\right)^{2}}{n}},
$$

and

$$
M E=\frac{\sum_{i=1}^{n}\left(Z_{i L i D A R}-Z_{\text {iground }}\right)}{n},
$$

where :

$Z$ is elevation, and

$n$ is the number of hydrogeomorphic comparisons.

The lower the RMSE and ME values, the better the agreement between the EAARL data and the ground-survey data. The ME helps identify bias while the RMSE defines the statistical error.

The guidelines of the American Society of Photogrammetry and Remote Sensing (2004) indicate that the dataset to be tested against (in this case, the ground-survey data) be at least three times more accurate than the dataset being tested (the LiDAR data). In this case, the ground-survey data has a vertical accuracy of $2 \mathrm{~cm}$ providing an acceptable comparison dataset for LiDAR data with vertical accuracies of $6 \mathrm{~cm}$ or more, which is better than the typical vertical accuracy of $15 \mathrm{~cm}$ for most LiDAR datasets. Potential sources of error that can affect accuracy are inherent in both LiDAR data collection and ground-surveying techniques. Errors in the LiDAR data can result from various sources, including, for example, vegetation, water clarity, GPS positioning error, inertial measurement of the aircraft attitude, and roughness of the measurement surface. These errors can be intrinsic to the data-collection process (for example, GPS positioning error) or be an artifact of the data-collection process (for example, roughness of the measurement surface).

The wetted cross-sectional areas also were compared. The wetted cross-sectional area was calculated for each measured cross-section for both the ground-survey data and the raster EAARL data, using the water-surface elevation from the ground-survey data. An accurate water-surface elevation could not be obtained from the EAARL first surface data due to highly variable elevations caused by the presence of vegetation. A percent error was calculated to compare the two measured wetted cross-sectional areas. 


\section{Comparison of Datasets}

The ME and RMSE for the EAARL raster and pointelevation data comparisons with the ground-survey data are shown in tables 1 and $\underline{2}$, respectively. The tables list the RMSE and ME for each hydrogeomorphic type and the grid measurements for each ground-survey area. Some hydrogeomorphic components were absent within the groundsurveyed area, which resulted in a not defined (n.d.) solution. The paucity of data for some hydrogeomorphic components, such as that for vegetation in the lower ground-survey area, results in a low statistical confidence for these comparisons and may not fully represent the true population.

\section{EAARL Raster and Ground-Survey Datasets}

The RMSE values for the comparison of the EAARL raster data to the ground-survey data (table 1) range from $0.082 \mathrm{~m}$ for the ground-survey area 3 grid to $0.637 \mathrm{~m}$ for the bank components in ground-survey area 2. Other than the low (n) RMSE value for the floodplain component of ground-survey area 2, the EAARL performs best in the grid measurements. The RMSEs in the grid areas $(0.082,0.106$, and $0.138 \mathrm{~m}$, respectively, for the ground-survey areas 1,2 , and 3) are similar to or better than other reported accuracies for EAARL-derived elevations (Kinzel and others, 2007; Barlow and others, 2008; Nayegandhi and others, 2009). The LiDAR performed well in the grid areas because their open and flat conditions minimized the potential for errors from the effects of vegetation, large slopes, or abrupt changes in slope that occur in the other hydrogeomorphic areas.

Table 1. Comparison of EAARL bare earth/bathymetry raster datasets to ground-survey data, lower Boise River, southwestern Idaho.

[Abbreviations: EAARL, Experimental Advanced Airborne Research LiDAR; n.d., not defined, which occurs when zero measurements were made in that hydrogeomorphic setting; n/a, not applicable]

Trees absent

Root Mean Square Error (m)

\begin{tabular}{l|c|c|c|c|} 
Ground-survey area & \multicolumn{1}{c}{$\mathbf{1}$} & $\mathbf{2}$ & $\mathbf{3}$ & \multicolumn{1}{c}{ Combined } \\
\cline { 2 - 5 } Channel & 0.292 & 0.400 & 0.571 & 0.440 \\
\cline { 2 - 5 } Bank & 0.199 & 0.637 & 0.289 & 0.371 \\
\cline { 2 - 5 } Floodplain & 0.184 & 0.090 & 0.158 & 0.159 \\
\cline { 2 - 5 } Grid & 0.138 & 0.106 & 0.082 & 0.111 \\
\hline
\end{tabular}

Mean Signed Error (m)

Ground survey area

Channel

Bank

Floodplain

Grid

\begin{tabular}{|c|c|c|c|}
\multicolumn{1}{c}{$\mathbf{1}$} & $\mathbf{2}$ & $\mathbf{3}$ & Combined \\
\hline-0.041 & 0.071 & 0.447 & 0.008 \\
\hline-0.134 & -0.076 & -0.112 & -0.109 \\
\hline-0.088 & -0.002 & -0.013 & -0.024 \\
\hline-0.095 & 0.008 & -0.017 & -0.035 \\
\hline
\end{tabular}

Number of Comparisons ( $\mathrm{n}$ )

Ground survey area

Channel

Bank

Floodplain

Grid

\begin{tabular}{|r|r|r|r|}
\multicolumn{1}{c}{1} & $\mathbf{2}$ & $\mathbf{3}$ & Combined \\
\hline 94 & 73 & 95 & 262 \\
\hline 15 & 14 & 42 & 71 \\
\hline 12 & 4 & 67 & 83 \\
\hline 100 & 100 & 100 & 300 \\
\hline
\end{tabular}

Trees present

Root Mean Square Error (m)

\begin{tabular}{|c|c|c|c|}
\multicolumn{1}{c}{1} & $\mathbf{2}$ & $\mathbf{3}$ & Combined \\
\hline 0.149 & 0.442 & n.d. & 0.361 \\
\hline 0.327 & 0.333 & 0.184 & 0.325 \\
\hline 0.496 & 0.190 & 0.201 & 0.433 \\
\hline n/a & n/a & n/a & n/a \\
\hline
\end{tabular}

Mean Signed Error (m)

\begin{tabular}{|c|c|c|c|}
\multicolumn{1}{c}{1} & \multicolumn{1}{c}{$\mathbf{2}$} & $\mathbf{3}$ & Combined \\
\hline 0.105 & 0.231 & n.d. & 0.184 \\
\hline-0.203 & -0.082 & -0.080 & -0.116 \\
\hline-0.382 & 0.073 & -0.063 & -0.262 \\
\hline n/a & n/a & n/a & n/a \\
\hline
\end{tabular}

Number of Comparisons ( $\mathrm{n}$ )

\begin{tabular}{|r|r|r|c|}
\multicolumn{1}{c}{1} & \multicolumn{1}{c}{$\mathbf{2}$} & 3 & Combined \\
\hline 6 & 10 & 0 & 16 \\
\hline 25 & 60 & 5 & 90 \\
\hline 44 & 14 & 3 & 61 \\
\hline n/a & n/a & n/a & n/a \\
\hline
\end{tabular}


Table 2. Comparison of EAARL bare-earth/bathymetry point datasets to ground-survey data within a 1-meter radius, lower Boise River, southwestern Idaho.

[Abbreviations: EAARL, Experimental Advanced Airborne Research LiDAR; n.d., not defined, which occurs when zero measurements were made in that hydrogeomorphic setting; n/a, not applicable]

Trees absent

Root Mean Square Error (m)

Ground-survey area

Channel

Bank

Floodplain

Grid

\begin{tabular}{|c|c|c|c|}
\multicolumn{1}{c}{1} & \multicolumn{1}{c}{$\mathbf{2}$} & $\mathbf{3}$ & Combined \\
\hline 0.249 & 0.289 & 0.583 & 0.413 \\
\hline 0.094 & 0.187 & 0.319 & 0.282 \\
\hline 0.298 & 0.100 & 0.208 & 0.221 \\
\hline 0.137 & 0.136 & 0.123 & 0.131 \\
\hline
\end{tabular}

Mean Signed Error (m)

Ground survey area

Channel

Bank

Floodplain

Grid

\begin{tabular}{|c|c|c|c|}
\multicolumn{1}{c}{1} & $\mathbf{2}$ & $\mathbf{3}$ & Combined \\
\hline 0.002 & 0.042 & 0.431 & -0.171 \\
\hline 0.033 & -0.100 & -0.162 & 0.130 \\
\hline-0.193 & -0.053 & 0.032 & 0.022 \\
\hline-0.066 & 0.001 & -0.031 & -0.032 \\
\hline
\end{tabular}

Number of Comparisons ( $\mathrm{n}$ )

Ground survey area

Channel

Bank

Floodplain

Grid

\begin{tabular}{|r|r|r|r|}
\multicolumn{1}{c}{1} & \multicolumn{1}{c}{$\mathbf{2}$} & $\mathbf{3}$ & Combined \\
\hline 48 & 32 & 47 & 127 \\
\hline 3 & 5 & 20 & 28 \\
\hline 8 & 4 & 28 & 40 \\
\hline 59 & 66 & 51 & 176 \\
\hline
\end{tabular}

Trees present

Root Mean Square Error (m)

\begin{tabular}{|c|c|c|c|}
\multicolumn{1}{c}{1} & \multicolumn{1}{c}{$\mathbf{2}$} & $\mathbf{3}$ & Combined \\
\hline 0.179 & 0.343 & n.d. & 0.314 \\
\hline 0.376 & 0.365 & 0.140 & 0.361 \\
\hline 0.551 & 0.219 & 0.178 & 0.478 \\
\hline n/a & n/a & n/a & n/a \\
\hline
\end{tabular}

Mean Signed Error (m)

\begin{tabular}{|c|c|c|c|}
\multicolumn{1}{c}{1} & $\mathbf{2}$ & $\mathbf{3}$ & Combined \\
\hline 0.179 & 0.307 & n.d. & -0.279 \\
\hline-0.090 & -0.176 & 0.113 & 0.147 \\
\hline-0.415 & 0.071 & 0.149 & 0.269 \\
\hline n/a & n/a & n/a & n/a \\
\hline
\end{tabular}

Number of Comparisons ( $\mathrm{n}$ )

\begin{tabular}{|r|r|r|c|}
\multicolumn{1}{c}{1} & \multicolumn{1}{c}{$\mathbf{2}$} & 3 & Combined \\
\hline 2 & 7 & 0 & 9 \\
\hline 10 & 37 & 2 & 49 \\
\hline 22 & 7 & 2 & 31 \\
\hline n/a & n/a & n/a & n/a \\
\hline
\end{tabular}

The EAARL data are affected by noise from random errors in the dataset and by the introduction of errors from specific sources, such as vegetation. Transect 3 in groundsurvey area 1 (fig. 2A) and transect 4 in ground-survey area 2 (fig. $2 B$ ) exemplify these error types. The LiDAR data performs well in these transects along the banks and in the channel except for false $1.5 \mathrm{~m}$ deep "holes" introduced in the channel by two inaccurate LiDAR elevation points. The floodplain along the left bank of transect 3 in ground-survey area 1 models the profile of the surface well, but with subdued relief. This area is heavily vegetated with large trees that are likely to be the source of error, as noted by the higher RMSE in areas with trees (table 1). The artificial "hole" in the stream also occurs in two other ground-survey transects-transect 1 of ground-survey area 1 and transect 2 in ground-survey area 2.

Five of the eight applicable RMSEs listed in table 1 have higher values for cases in which trees are present. Of the three exceptions, two are for areas with few ground-truth survey points (low n), and hence have a weak statistical significance, while steep slopes on the banks influence the other value. Steep slopes exacerbate the horizontal positioning error effect, which results when differences in elevation are due not only to the usual factors that affect the accuracy of LiDAR system data but also because LiDAR and ground-survey points do not exist within a reasonable distance from each other. The horizontal location error is then translated to the raster by means of the interpolator used to make the raster. Although the EAARL system is designed to work in vegetated areas (U.S. Geological Survey, 2007a; Nayegandhi and others, 2009), this study indicates that dense vegetation introduces additional error as compared to values for non-vegetated or sparsely vegetated areas. Additional post-processing with manual filtering may improve the RMSE values through removal of vegetation effects.

In ground-survey area 3, the channel hydrogeomorphic setting has the largest RMSE values. This is due to the effect of high turbidity in the stream on the EAARL system's ability to measure bathymetry. High levels of turbidity absorb or scatter most of the EAARL's laser energy, thereby preventing a return signal from the streambed that is strong and clean enough to assess the depth (ig. 3 ). Turbidity did not introduce errors in upstream ground-survey areas 1 or 2 , where the Boise River has low turbidity. 


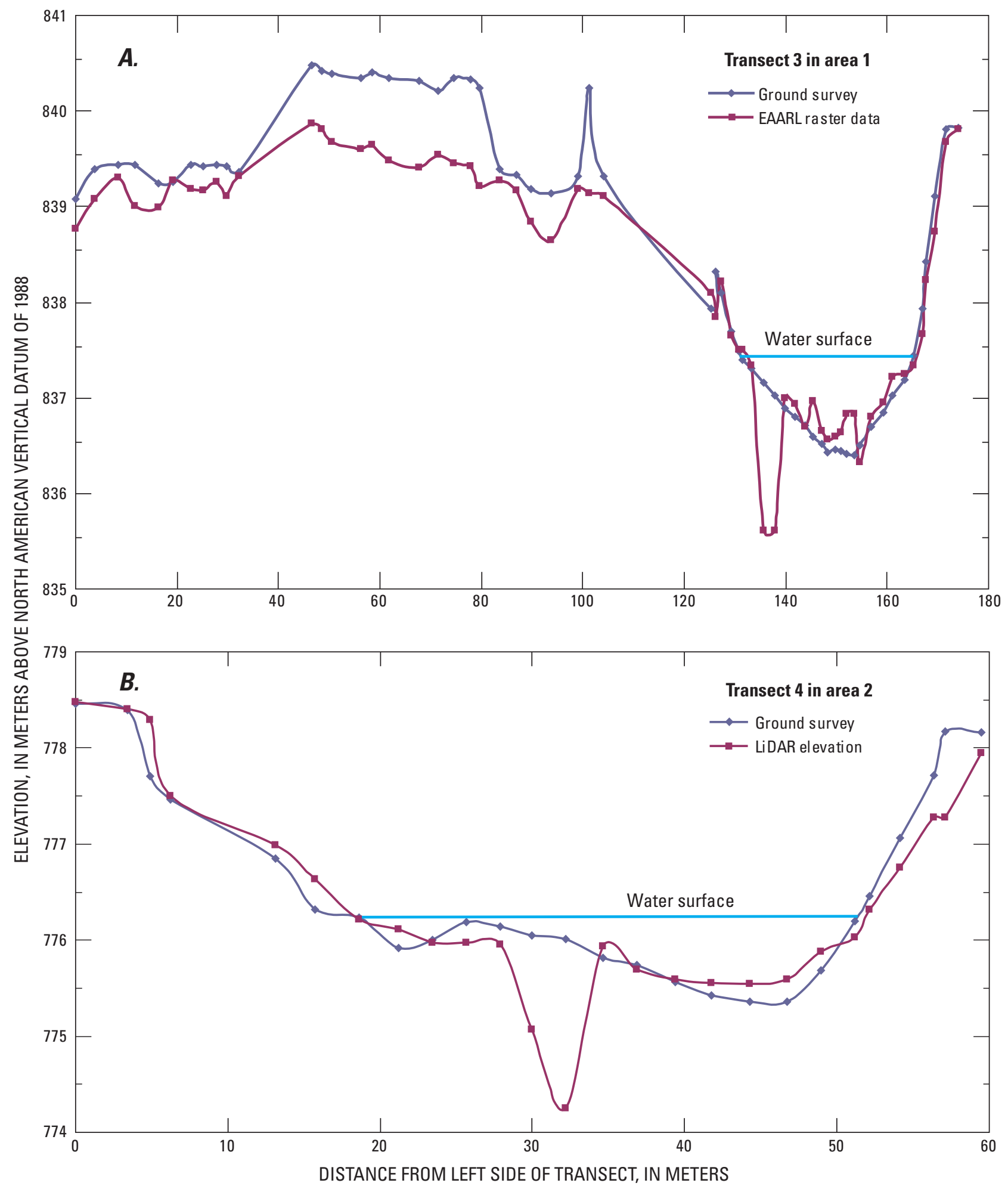

Figure 2. EAARL raster and ground-survey elevations at two transects, lower Boise River, southwestern Idaho. 


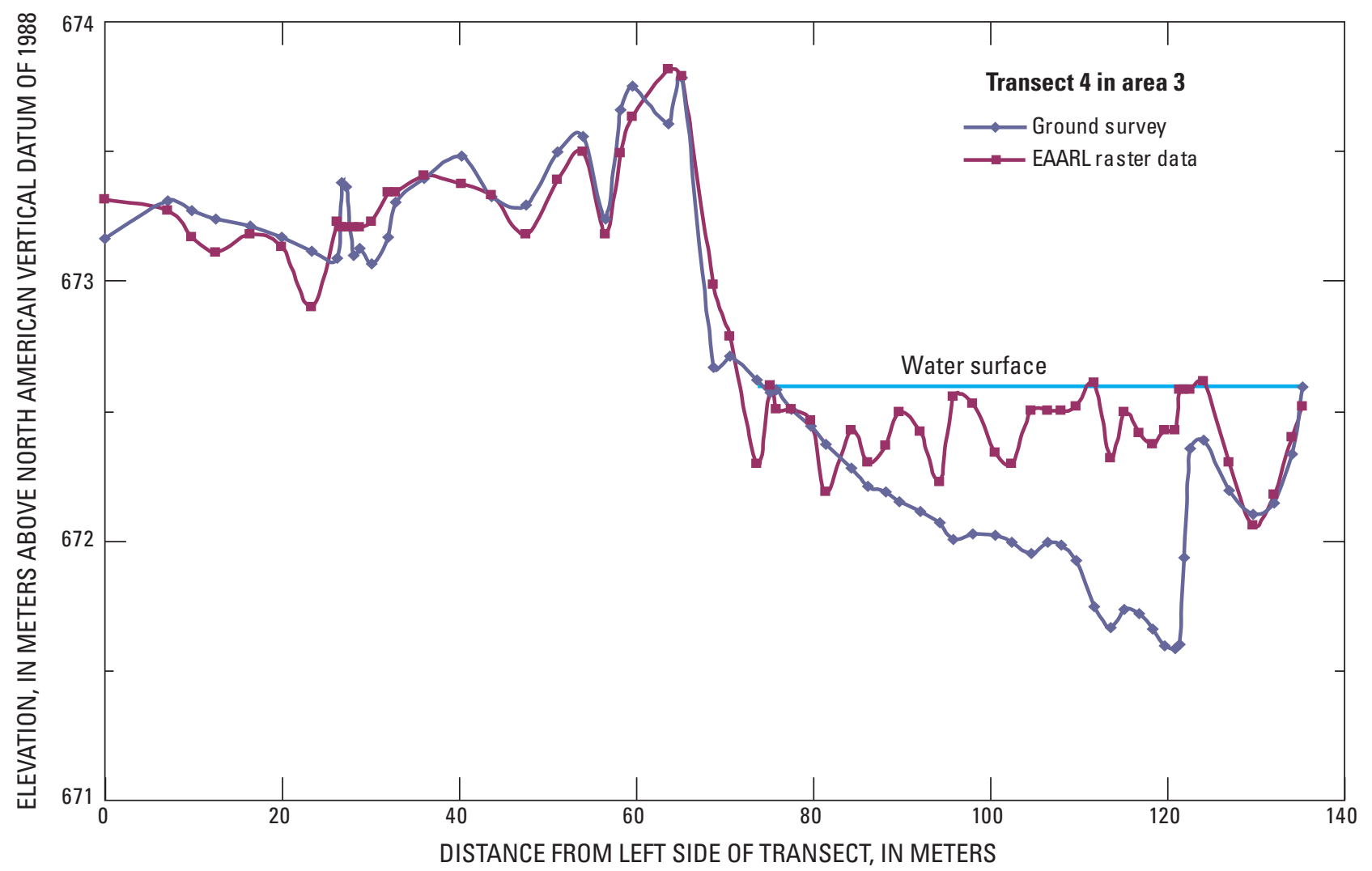

Figure 3. EAARL raster and ground-survey data at transect 4 of ground-survey area 3, lower Boise River, southwestern Idaho.

RMSE values for stream bathymetry are about twice as high as the corresponding grid RMSE values for each ground-survey area. Surveyed water depths range up to $1.1 \mathrm{~m}$ in ground-survey area $1,1.0 \mathrm{~m}$ in ground-survey area 2, and up to $1.2 \mathrm{~m}$ in ground-survey area 3 . Mean surveyed depths are $0.38 \mathrm{~m}$ for ground-survey area $1,0.31 \mathrm{~m}$ for groundsurvey area 2 , and $0.57 \mathrm{~m}$ for ground-survey area 3 . However, because streams depths along the transects in ground-survey area 3 were too deep to wade, the mean surveyed depth is less than the actual mean depth. The increased RMSE is not affected by these shallow water depths, or by substrate. The stream channel in ground-survey area 2 typically has a smaller substrate than that in ground-survey area 1 , which should result in an improved RMSE because of a reduced channel roughness, resulting in less scatter of the EAARL signal. The bathymetric point density is less than that for the bare-earth points, which may lead to inaccuracies in interpolation of the points to make the raster datasets. Again, the increased RMSE for ground-survey area 3 is due to high turbidity levels in the stream.

\section{Wetted Cross-Sectional Area Percent Error}

The percent error between the wetted cross-sectional areas computed from the ground-survey data and the EAARL raster data had a mean of 1 percent for ground-survey areas 1 and 2 indicating that with surface differences between the two elevation datasets, the overall wetted cross-sectional area is similar. If ground-survey area 3 is included in the calculation, the mean percent difference increases to -18 percent. This again shows the effects of turbidity on the EAARL system in ground-survey area 3.

Individual ground-survey area results were similar. Ground-survey area 1 had a minimum percent error of -6 percent, a maximum of 30 percent, and a mean of 8 percent. Ground-survey area 2 was more variable with a minimum percent error of -6 percent, a maximum of -54 percent, and a mean of -6 percent. The effects of turbidity in ground-survey area 3 resulted in a minimum percent error of -27 percent, a maximum of -83 percent, and a mean of -56 percent in the wetted cross sectional areas computed from the two datasets. 


\section{EAARL Point and Ground-Survey Datasets}

Comparisons between the EAARL point dataset and the ground-survey dataset are presented in table 2. Fewer comparisons (n) are possible between the EAARL point and ground-survey datasets than between the EAARL raster and ground-survey datasets because not all ground-survey points had a corresponding EAARL point within the required 1 -m radius for the comparison. The 1-m distance limitation was selected to reduce any spatial variance that could be introduced if the points were not within an acceptable proximity to each other. The elevation change within a 1-m distance was assumed to be negligible. The streambank hydrogeomorphic setting is the most likely to violate this assumption.

The comparison of EAARL point to ground-survey data produced results similar to those for the EAARL raster to ground-survey comparisons even with low sample sizes for some of the categories. Such similar results indicate that the interpolation from the EAARL points to the EAARL raster datasets did not introduce additional error.

\section{Analysis for Bias}

The mean signed error (ME) comparison results do not indicate a consistent bias in any of the ground-survey areas or their hydrogeomorphic settings (tables 1 and 2). Therefore, neither a block shift nor other bias corrections were applied to the datasets. Although all of ground-survey area 1 mean errors are negative (implying a positive bias for the ground-survey data), the mean errors for the other two areas are neither consistently positive nor negative throughout their areas or hydrogeomorphic settings. The only large bias was found in the channel data for ground-survey area 3; however, this is a consequence of high turbidity in the stream and is not a bias in the datasets.

\section{Summary}

To assist in addressing issues such as flooding, water quality, and water supply along the lower Boise River, Idaho, high-resolution topographic and bathymetric data of the river reach and associated floodplain were acquired using the Experimental Advanced Airborne Research LiDAR (EAARL) system.

To evaluate the accuracy of the EAARL system's elevation products and to account for the many possible uses of the EAARL data, it was necessary to conduct a ground-truth analysis in the various hydrogeomorphic settings related to the Boise River throughout the lower Boise River basin. Ground-truth data were collected in three areas along the river concurrent with the collection of EAARL system data using a RTK-GPS survey system and a total station, which together provided elevation and positional accuracies ranging from 2 to $3 \mathrm{~cm}$. The three ground-survey areas were selected to represent the variations in hydrogeomorphic settings in the valley. Each ground-survey area included a grid of measurements in a flat, open area to provide an optimal vertical comparison surface for the EAARL and ground-survey data. Additional ground surveys were conducted across the Boise River to determine accuracy levels for assessing hydrogeomorphic settings, such as bank slope, bathymetry, areas of dense vegetation or trees, and wetted cross-sectional areas.

Both the point LiDAR and raster datasets were compared with data from the ground- surveys. Root mean square errors were calculated for the grid surveys to assess the accuracy of the LiDAR datasets with minimal introduction of error, and ranged from 0.082 to $0.138 \mathrm{~m}$. These results compare favorably with those of other bathymetry-type LiDAR systems. Accuracies representing the various hydrogeomorphic settings range from 0.090 to $0.637 \mathrm{~m}$. Of the three hydrogeomorphic settings assessed (in-stream channel, streambanks, and adjacent floodplain), elevations for the floodplain are the most accurate, with the elevations for channel and bank features having similar accuracies. The presence of trees in any of the three hydrogeomorphic settings can result in a decrease of accuracy. This is most noticeable in the floodplain areas due to the high density of trees there. High stream turbidity prevented the EAARL system from measuring accurate elevations in ground-survey area 3 . The EAARL system performance begins to be affected by turbidity within the 4.2-19.3 NTU range. The largest source of error in the bank comparisons is a steep slope, which exacerbates the vertical error due to horizontal spatial differences between the EAARL and ground-survey datasets, thereby invalidating the assumption that ground-survey and EAARL points near each other represent the same location. The mean percent error for the wetted cross-sectional areas of ground-survey areas 1 and 2 was 1 percent. The mean percent error increases to -18 percent when the downstream ground-survey area is included, reflecting the influence of turbidity in ground-survey area 3 . Statistically valid comparisons between the EAARL point to ground-survey datasets produced similar results as the EAARL raster to ground-survey comparisons, indicating that the interpolation of the EAARL points to rasters did not introduce significant additional error. 


\section{References Cited}

American Society of Photogrammetry and Remote Sensing, 2004, ASPRS guidelines, Vertical accuracy reporting for LiDAR data, Version 1.0, May 24, 2004, accessed April 1, 2009, at http://www.asprs.org/society/committees/lidar/ downloads/Vertical Accuracy Reporting for Lidar Data. pdf.

Bales, J.D., Wagner, C.R., Tighe, K.C., and Terziotti, Silvia, 2007, LiDAR-derived flood-inundation maps for realtime flood-mapping applications, Tar River Basin, North Carolina: U.S. Geological Survey Scientific Investigations Report 2007-5032, 42 p. Available at http://pubs.usgs.gov/ sir/2007/5032/.

Barlow, R.A., Nardi, M.R., and Reyes, Betzaida, 2008, Use of Light Detection and Ranging (LiDAR) to obtain highresolution elevation data for Sussex County, Delaware: U.S. Geological Survey Fact Sheet 2008-3088, 6 p. Available at http://pubs.usgs.gov/fs/2008/3088/.

Kinzel, P.J., Wright, W.C., Nelson, J.M., and Burman, A.R., 2007, Evaluation of an experimental LiDAR for surveying a shallow, braided, sand-bedded river: Journal of Hydraulic Engineering, v. 133, p. 838-842.

Nayegandhi, A., Brock, J.C., and Wright, C.W., 2009, Small-footprint, waveform-resolving LiDAR estimation of submerged and sub-canopy topography in coastal environments: International Journal of Remote Sensing, v. 30, no. 4, p. 861-878.

Notebaert, Bastiaan, Verstraeten, Gert, Govers, Gerard, and Poeson, Jean, 2009, Qualitative and quantitative applications of LiDAR imagery in fluvial geomorphology: Earth Surface Processes and Landforms, v. 34, p. 217-231.
Roman, D.R., Wang, Yan Ming, Henning, William, and Hamilton, John, 2004, Technical Sessions: Assessment of the New National Geoid Model, GEOID03: ACSM/ TAPS Conference and Technology Exhibition, Nashville, Tennessee, 2004, 14 p.

Snay, R.A., and Soler, Tomas, 2008, Continuously Operating Reference Station (CORS): History, Applications, and Future Enhancements: Journal of Surveying Engineering, v. 134, Issue 4, p. 95-104.

Trimble Navigation Limited, 2003, Trimble R7/R8 GPS Receiver User Guide, Version 1.00, Revision A, Sunnyvale, California, Trimble Navigation Limited, 216 p.

Trimble Navigation Limited, 2005, Trimble Geomatics Office, Version 1.63, Build 10, Sunnyvale, California, Trimble Navigation Limited.

U.S. Census Bureau, 2009, State and County QuickFacts, accessed May 2009 at http://quickfacts.census.gov/qfd/ states/16000.html.

U.S. Geological Survey, 2007a, Center for Coastal and Watershed Studies, Integrated Remote Sensing and Modeling Group, Advanced methods, EAARL—Airborne LiDAR system for high-resolution submerged and subaerial topography, accessed April 1, 2009, at http://ngom. usgs.gov/dsp/tech/eaarl/.

U.S. Geological Survey, 2007b, Center for Coastal and Watershed Studies, Integrated Remote Sensing and Modeling Group, Advanced methods, LiDAR processing systems, accessed April 1, 2009, at http://ngom.usgs.gov/ dsp/tech/alps/.

Weston, N.D., Soler, Tomas, and Mader, G.L., 2007, Web-based solution for GPS data. NOAA OPUS, GIM International, v. 21, issue 4, p. 23-25. 
Publishing support provided by the U.S. Geological Survey Publishing Network, Tacoma Publishing Service Center

For more information concerning the research in this report, contact the Director, Idaho Water Science Center U.S. Geological Survey

230 Collins Road

Boise, Idaho 83702

http://id.water.usgs.gov 


\section{애용}

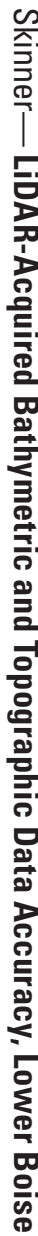

꼻



ธั

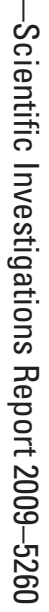

